\title{
スギ・カラマツ構造用集成材の高温時の圧縮挙動に及ぼす水分の影響 INFLUENCE OF MOISTURE ON COMPRESSIVE BEHAVIOR OF JAPANESE CEDAR AND LARCH STRUCTURAL GLULAM TIMBERS AT ELEVATED TEMPERATURE
}

\author{
菊地毅 之*1, 平島岳夫*2
}

\section{Takayuki KIKUCHI and Takeo HIRASHIMA}

In this study, elevated temperature compression tests of structural glulam timber were conducted in order to investigate the influence of temperature and moisture on the compressive behavior, and the following results were indicated. Compressive strength and modulus of elasticity of the specimen exposed to heating effects below $200{ }^{\circ} \mathrm{C}$ decreased significantly up to 1 hour and became the minimum during 1 to 2 hours. Influences of moisture in the specimens on the compressive behavior were discussed from the test results on the relationships of heating time and weight change. The stress-strain curve for compression was approximated by Richard's equation.

Keywords: Structural glulam timber, Elevated temperature, Moisture, Compressive strength, Modulus of elasticity, Stress-strain curve 構造用集成材，高温，水分，圧縮強度，弾性係数，応力一ひず夕曲線

\section{1. はじめに}

木材は熱伝導率が小さいため, 大断面部材を用いた木質構造では, 火災加熱を受けたときに炭化層の内側 (非炭化領域) の温度が低く, 非炭化領域で荷重を支持できる。一方，木質部材の場合，火災加熱 後の放冷過程においても非炭化領域の温度が徐々に上昇し, 部材の 剛性と耐力は低下寸る 1), 2)。したがって，木質構造の火災時におけ る構造安定性を放冷過程も含めて検討するには, 非炭化領域の温度 上昇に伴う剛性・耐力の変化を把握し, 木材の高温力学特性を適切 に設定する必要がある。木材の含水率は強度に影響を及ぼすが，高 温時においても木材中の水分はその強度と弾性係数の変化に大きな 影響を及ぼす 3)。しかしながら，水分の影響をより大きく受ける高 温時の圧縮挙動に着目した研究は少なく, 解析で必要となる応力ーひ ずみ関係に関する高温時データもないのが現状である。

Eurocode5 4)の付録では, 先進的な火災応答解析に用いるための 高温力学特性として, 針葉樹の木材について水分の影響をも含む強 度と弾性係数の温度依存性が示されている5)。Eurocode5 の值は, 火災加熱を受ける部材の曲げ挙動の分析 $\left.{ }^{6}\right)$ より与えられたもので あり，国産材を用いた梁・柱の載荷加熱実験での挙動も比較的追跡 できている 1), 2)。また国産材の高温素材試験データも近年蓄積され ている。加來らは, 含水率を実験変数とした無欠点小試験体の高温
曲げ実験により, 含水率 $30 \%$ 以下のスギとケヤキでは, 含水率が高 いほど $100^{\circ} \mathrm{C}$ 未満における曲げ強度とヤング係数の低下が著しくな る結果を示した7)。また渡辺らは，更にヒノキ・カラマッ・ベイマ ツのデータを加えて, 高温時の曲げ強度・ヤング率と含水率の関係 を樹種別に定量化した 8)。一方，木材の水分が高温特性に及ぼす影 響は圧縮挙動時に顕著であると報告されているが 3)，素材の高温圧 縮実験により水分の影響が検討された研究例は少ない。またファイ バーモデルを用いた構造解析では圧縮・引張それぞれの高温時の応 カーひずみ関係を与える必要があるが，その実験データはなく，応 力ーひずみ関係を得るには軸方向加力の実験が必要である。

そこで本研究では，スギ・カラマツ構造用集成材の高温圧縮挙動 に及ぼす水分の影響把握および高温時応力ーひずみ関係の取得を目 的として，その高温圧縮実験を実施した。既往研究 3),7),8)では含水 率を実験変数として水分の影響が検討されたが，本研究では梁・柱 の載荷加熱実験 1), 2) に用いた構造用集成材の解析モデル取得も 1 つ の目的であるため, 含水率ではなく加熱時間を主たる実験変数とし て水分の影響について検討した。木材の加熱において, 水分の蒸発 や熱分解による重量減少が起こるが，本研究では水分量の変化（蒸 発量）は試験体重量の変化と同じとし，高温圧縮強度・ヤング率と 試験体重量の変化の関係を考察した。なお本報告は，既報 9), 10)の実

\footnotetext{
*1 千葉大学融合理工学府 大学院生 · 修士 (工学) / 千葉大学工学部 技術職員

Grad. Student, Graduate school of Science and Engineering, Chiba Univ., M.Eng./

*2 千葉大学大学院工学研究院 教授 $\cdot$ 博士 (工学)

Prof., Graduate School of Engineering, Chiba Univ., Dr.Eng.
} 
験データを再整理して考察を加えたものである。

\section{2. 実験概要}

\section{1 実験条件および試験体}

実験条件は, Table 1〜Table 3 に示寸ように，樹種・ヒーターの 設定温度・加熱時間とした。Table 2 と Table 3 の中の数字は試験体 数を示す。シリーズ I では，コンプレッソメーターを用いて圧縮変 形を測定し，スギとカラマツの荷重一変形関係を得た。一方，シリ ーズ II は，カラマツの圧縮強度のみを検討対象とした。なお，シリ ーズ II は, カラマツ梁の載荷加熱実験 1)に関連して実施されたもの である。本研究では, 常温実験をシリーズ I では 15 体ずつ, シリー ズ II で 5 体実施した。シリーズ I の 15 体の常温圧縮強度のばらつ きは, スギでは平均值 $34.0 \mathrm{~N} / \mathrm{mm}^{2}$ に対する標準偏差が $3.50 \mathrm{~N} / \mathrm{mm}^{2}$ (変動係数 : $10.3 \%$ ), カラマツでは平均值 $48.5 \mathrm{~N} / \mathrm{mm}^{2}$ に対する 標準偏差が $2.94 \mathrm{~N} / \mathrm{mm}^{2}$ （変動係数：6.1\%）であった。シリーズ II のカラマツの常温圧縮強度の変動係数は 5 体の結果ではあるが, $5.3 \%$ あった。これらのばらつきは, 木材の試験としては小さいと 考える。ばらつきが小さい理由は, 構造用集成材を用いていること と, 曲げや引張・せん断強度に比べて圧縮強度のばらつきが小さい ためと考える ${ }^{11)}$ 。以上より高温実験では，試験体数を 1 としても， 加熱温度と加熱時間による压縮強度の変化を把握できると考えた。

最大加熱時間は，試験体が十分に乾燥し重量減少が一定になる時 間を想定し，シリーズ I では 22 時間, シリーズ II では 66 時間とし た。シリーズ I で，シリーズ II より加熱時間を短くした理由は，試 験体寸法が小さく 22 時間の加熱で水分の蒸発後における強度回復 が確認できると考えたためである。また, 高温履歴を経た後の圧縮 強度を確認するために, 加熱時間が最長の試験体を自然放冷した圧 縮実験をシリーズ I で実施した。 $150^{\circ} \mathrm{C}$ を超える温度での長時間加 熱は着火の危険性があるため, シリーズ I の $200^{\circ} \mathrm{C}$ 実験での加熱時 間は，スギは 4 時間まで，カラマツは 6 時間までとした。シリーズ $\mathrm{I}$ ・スギ・ $200^{\circ} \mathrm{C}$ で加熱を行った際，4〜5 時間の間でヒーター内の試 験体の 1 つが着火していた。

試験体の材料データを Table 4 に示す。試験体に用いたラミナの 等級は，スギは L70，カラマツは L100 とした。全試験体とも同一 等級構成集成材とし，スギ試験体の強度等級は E65-F240, カラマ ツ試験体の強度等級はシリーズ I が E95-F285 でシリーズ II が E95F315 である。接着剤にはレゾルシノール・フェノール樹脂を用い た。密度と含水率の值は, Table 5 に示寸通り, シリーズ I では $100^{\circ} \mathrm{C}$

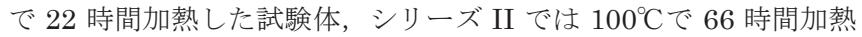
した試験体の重量から得た。本試験体の含水率は 8 9\%程度で, カ ラマツの方がスギよりも若干大きかった。

試験体の概要を Fig.1（シリーズ I）および Fig.2（シリーズ II） にそれぞれ示す。全試験体とも繊維方向の圧縮試験体である。本研 究では構造用集成材による柱や梁による挙動を検討するための実験 であるため, ラミナ積層数を 3 または 4 とし, 一般的な圧縮試験片 の辺長 20〜30mm（JIS Z 2101：2009)よりも大きな断面寸法とし た。また, 節による久点も含む構造用集成材を対象とし, 高温加熱 直後に変位測定を行う都合, 試験体の断面寸法はシリーズ I で $75 \times 75 \mathrm{~mm}$ とした。シリーズ II では 105×105mm とした。これより 加熱時に断面内部に温度勾配が生じるため, Fig. 1 と Fig.2 に示す
ように熱電対を挿入した温度計測用試験体を作成し, 試験体の内部 温度と加熱時間の関係を把握した。圧縮実験に使用寸る試験体には 熱電対を挿入しなかった。

Table 1 Test program (All Series)

\begin{tabular}{|c|c|c|c|c|}
\hline \multirow[b]{2}{*}{ Series } & \multirow{2}{*}{$\begin{array}{c}\text { Tree } \\
\text { species }\end{array}$} & \multicolumn{2}{|c|}{ Thermal condition } & \multirow{2}{*}{$\begin{array}{l}\text { Specimen } \\
\text { size }[\mathrm{mm}]\end{array}$} \\
\hline & & $\begin{array}{c}\text { Constant } \\
\text { temperatures }\left[{ }^{\circ} \mathrm{C}\right]\end{array}$ & $\begin{array}{c}\text { Heating time } \\
\text { [hour] }\end{array}$ & \\
\hline I & $\begin{array}{l}\text { Cedar } \\
\text { Larch }\end{array}$ & $\begin{array}{c}\text { Ambient Temp., } \\
60 \sim 200\end{array}$ & $\begin{array}{l}0.5 \sim 22 \\
\text { Natural } \\
\text { cooling }\end{array}$ & $75 \times 75 \times 300$ \\
\hline II & Larch & $\begin{array}{c}\text { Ambient Temp. } \\
75 \sim 175\end{array}$ & $0.5 \sim 66$ & $105 \times 105 \times 315$ \\
\hline
\end{tabular}

Table 2 Test program (Series I )

\begin{tabular}{c|c|c|c|c|c|c|c|c|c|c|c|c}
\hline \multicolumn{10}{c|}{ Series I Thermal condition (Cedar \& Larch) } & Total \\
\hline Ambient Temp. & \multicolumn{10}{c}{15} & 15 \\
\hline $\begin{array}{c}\text { Constant } \\
\text { temperatures }\left[{ }^{\circ} \mathrm{C}\right]\end{array}$ & \multicolumn{10}{c|}{ Cooling } & \\
\hline \hline 60 & 1 & 1 & 1 & 1 & 1 & 1 & 1 & 1 & 1 & 2 & 2 & 13 \\
\hline 100 & 1 & 1 & 1 & 1 & 1 & 1 & 1 & 1 & 1 & 2 & 2 & 13 \\
\hline 150 & 1 & 1 & 1 & 1 & 1 & 1 & 1 & 1 & 1 & 2 & 2 & 13 \\
\hline 200 & 1 & 1 & 1 & 1 & 1 & 1 & 1 & 1 & 1 & 0 & 2 & 11 \\
\hline
\end{tabular}

Table 3 Test program (Series II )

\begin{tabular}{c|c|c|c|c|c|c|c|c}
\hline \multicolumn{7}{|c|}{ Series II Thermal condition (Larch) } & Total \\
\hline Ambient Temp. & \multicolumn{7}{c|}{5} & 5 \\
\hline $\begin{array}{c}\text { Constant } \\
\text { temperatures }\left[{ }^{\circ} \mathrm{C}\right]\end{array}$ & 1 & 2 & 4 & 8 & 16 & 31 & 66 & \\
\hline \hline 75 & 1 & 1 & 1 & 1 & 0 & 1 & 0 & 5 \\
\hline 100 & 2 & 2 & 2 & 2 & 2 & 2 & 2 & 14 \\
\hline 125 & 1 & 1 & 1 & 1 & 1 & 1 & 1 & 7 \\
\hline 150 & 2 & 2 & 2 & 2 & 2 & 2 & 2 & 14 \\
\hline 175 & 1 & 1 & 1 & 1 & 1 & 0 & 0 & 5 \\
\hline
\end{tabular}

Table 4 Material data

\begin{tabular}{c|c|c|c}
\hline \multirow{2}{*}{ Series } & \multicolumn{2}{|c|}{ I } & II \\
\cline { 2 - 4 } & Cedar & Larch & Larch \\
\hline \hline Lamina layer & \multicolumn{2}{|c|}{$25 \mathrm{~mm} \times 3$} & $26.25 \mathrm{~mm} \times 4$ \\
\hline Lamina Grade & L70 & L100 & L100 \\
\hline Specimen size $[\mathrm{mm}]$ & \multicolumn{2}{|c|}{$75 \times 75 \times 300$} & $105 \times 105 \times 315$ \\
\hline Oven-dry density $\left[\mathrm{g} / \mathrm{cm}^{3}\right]$ & 0.37 & 0.50 & 0.49 \\
\hline Water content [\%] & 8.5 & 9.0 & 9.3 \\
\hline Adhesive type & \multicolumn{4}{|c|}{ Resorcinol phenol resin adhesive } \\
\hline
\end{tabular}

Table 5 Oven-dry density \& Water content

\begin{tabular}{|c|c|c|c|c|c|c|c|c|}
\hline \multicolumn{3}{|c|}{$100^{\circ} \mathrm{C}$} & \multicolumn{2}{|c|}{ Mass } & \multicolumn{2}{|c|}{ Oven-dry density } & \multicolumn{2}{|c|}{ Water content } \\
\hline \multirow{2}{*}{\multicolumn{2}{|c|}{ Series }} & \multirow{2}{*}{ Time } & Before & After & Value & Average & Value & Average \\
\hline & & & [g] & [g] & {$\left[\mathrm{g} / \mathrm{cm}^{3}\right]$} & {$\left[\mathrm{g} / \mathrm{cm}^{3}\right]$} & [\%] & [\%] \\
\hline \multirow{4}{*}{ I } & \multirow{2}{*}{ Cedar } & $22 \mathrm{~h}-1$ & 697.2 & 645.0 & 0.38 & \multirow{2}{*}{0.37} & 8.1 & \multirow{2}{*}{8.5} \\
\hline & & $22 \mathrm{~h}-2$ & 656.3 & 602.5 & 0.36 & & 8.9 & \\
\hline & \multirow{2}{*}{ Larch } & $22 \mathrm{~h}-1$ & 920.2 & 841.2 & 0.50 & \multirow{2}{*}{0.50} & 9.4 & \multirow{2}{*}{9.0} \\
\hline & & $22 \mathrm{~h}-2$ & 929.6 & 856.3 & 0.51 & & 8.6 & \\
\hline \multirow{2}{*}{ II } & \multirow{2}{*}{ Larch } & $66 \mathrm{~h}-1$ & 1869.8 & 1700.3 & 0.49 & \multirow{2}{*}{0.49} & 10.0 & \multirow{2}{*}{9.3} \\
\hline & & 66h-2 & 1833.0 & 1686.5 & 0.49 & & 8.7 & \\
\hline
\end{tabular}

\section{2 実験方法}

実験に用いたヒーターおよび試験体の設置状況例（シリーズ I, $200^{\circ} \mathrm{C}$ ）を Fig. 3 に示す。試験体の加熱には， $200^{\circ} \mathrm{C}$ まで加熱可能な 恒温ヒーターを用いた。樹種と試験温度が同じ圧縮実験用試験体と 温度計測用試験体をヒーター内に設置し，加熱開始後はヒーターの 設定温度を一定に保持して，所定の時間まで試験体を加熱した。ヒ 
ーターから取り出した後, 速やかに試験体の重量を測定して圧縮実 験を行った。ヒーターから取り出し, 実験が終了寸るまでの時間は すべてのシリーズにおいて 10 分程度であった。圧縮試験機および 変形測定治具を Fig.4 に示す。圧縮試験には載荷能力 $1 \mathrm{MN}$ のアム スラー圧縮試験機を用い, 荷重計測用に試験体下部にロードセルを 設置し，相対変位の測定にはコンプレッソメーターを用いた。シリ ーズ I の実験では, 容量 $5 \mathrm{~mm}$ ・精度 $0.0005 \mathrm{~mm}$ の変位計を左右に 設置し，変位測定区間 $150 \mathrm{~mm}$ における圧縮変形量を測定した。

\section{3 温度測定結果}

ヒーター内に設置した温度測定用試験体の内部温度の推移を Fig.5 の(a)と(b)に示す。Fig.5 の(a)に示す断面寸法 $75 \times 75 \mathrm{~mm}$ の場 合は表面から $9.4 \mathrm{~mm}$ の温度と中心部の温度差が約 $20^{\circ} \mathrm{C}$ 以下に収ま っているが, Fig.5 の(b)に示す断面寸法 105×105mm の場合は表面 から $13 \mathrm{~mm}$ の温度と中心部の温度差は $20^{\circ} \mathrm{C} \sim 30^{\circ} \mathrm{C}$ あ゙あた。また Fig.5 の(b)より, 試験体表面で計測した温度は, 加熱 3 時間位まで 表面から $13 \mathrm{~mm}$ の温度よりも $20^{\circ} \mathrm{C} \sim 30^{\circ} \mathrm{C}$ 高い温度を示した。 $150^{\circ} \mathrm{C} \cdot 200^{\circ} \mathrm{C}$ 実験では試験体内部の温度がヒーター設定温度に近 づくのに 8 時間以上を要した。Fig. 6 に示寸試験体の内部温度は,

Fig. 1 に示す 3 箇所の温度測定結果の平均温度である。例えば, Fig. 6 に示す $150^{\circ} \mathrm{C}$ のラマツの結果は, Fig.5(a)に示す(1)〜(3)の内部温度 の平均值である。Fig.6 に示すように, スギとカラマツの内部温度の

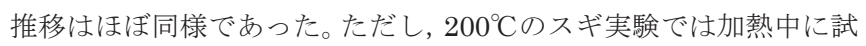
験体の赤熱・発火が生じたため 4 時間以降の実験は中止した。 Fig.7(a)と(b)は, シリーズ I と同じ試験体寸法・加熱条件で行った 追加実験において, ヒーターから取り出した後の圧縮強度実験中に おける試験体（Fig.1の（1)と（3)の 2 点の平均）の温度低下に関寸る 結果である。木材は熱伝導率が小さいためヒーターから取り出した

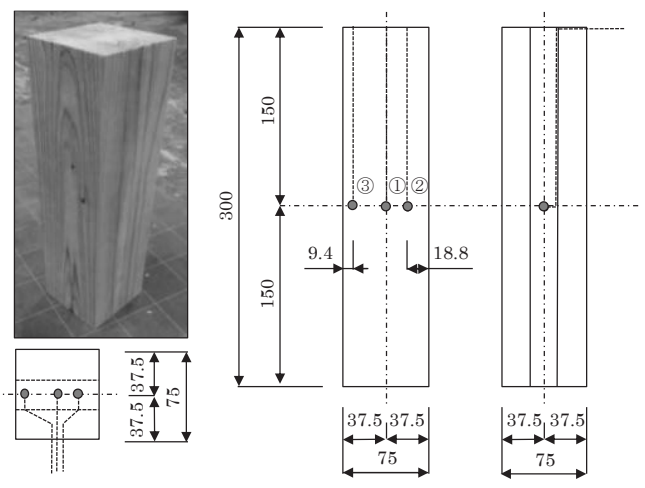

Fig. 1 Test specimen (Series I )

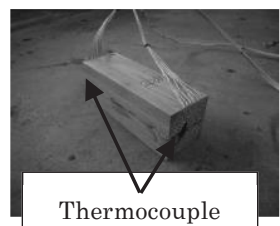

Thermocouple

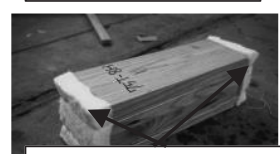

Thermal Insulation materials

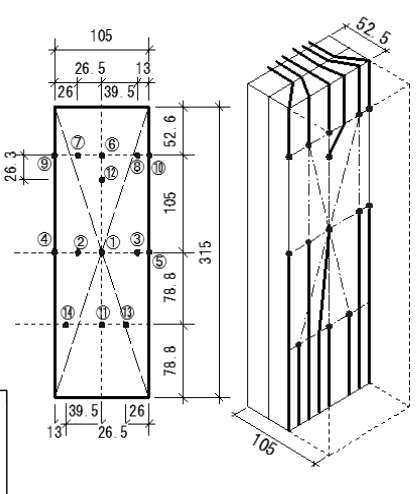

Fig.2 Test specimen (Series II )
後の試験体の内部温度の低下は比較的緩やかであるが, 表面から $9.4 \mathrm{~mm}$ の温度は圧縮実験が終了寸るまでの 10 分以内でも $10^{\circ} \mathrm{C}$ 位 の低下が見られた。試験体表面付近の温度はさらに低下していたと 考えられる。本実験は高温加熱直後に実施した圧縮実験であるが,

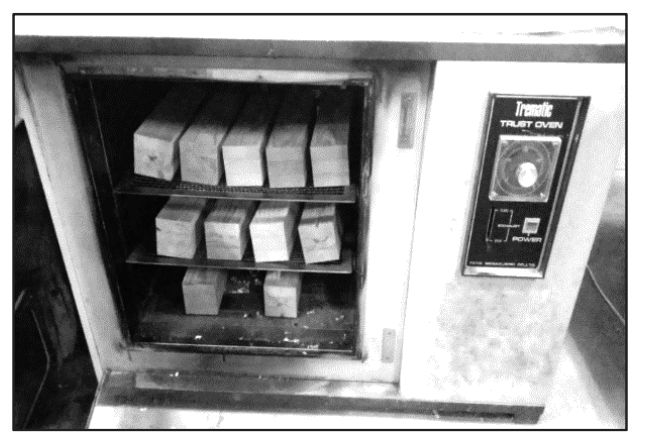

Fig. 3 Heater (Series I, $200^{\circ} \mathrm{C}$ )

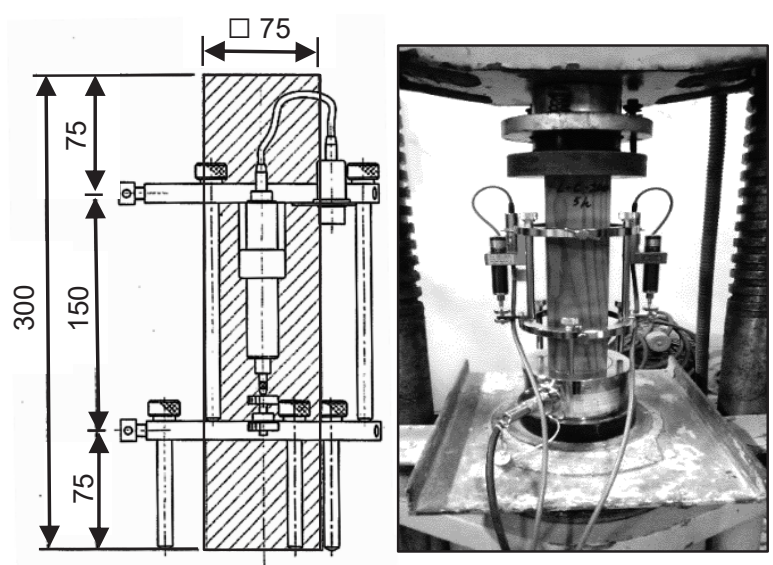

Fig. 4 Test setup for compression test (Series I, $200^{\circ} \mathrm{C}$ )

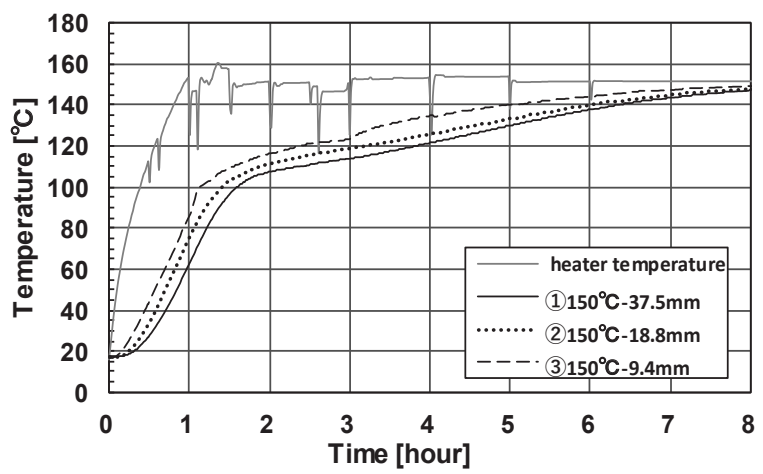

(a) An example of Series I ( $75 \times 75 \mathrm{~mm}$, Larch, $\left.150^{\circ} \mathrm{C}\right)$

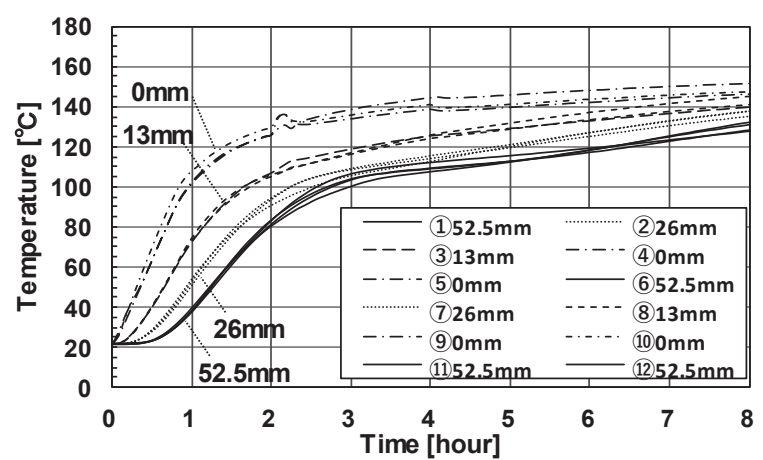

(b) An example of Series II (105x105mm, Larch, $\left.150^{\circ} \mathrm{C}\right)$

Fig.5 Result of temperature distribution 


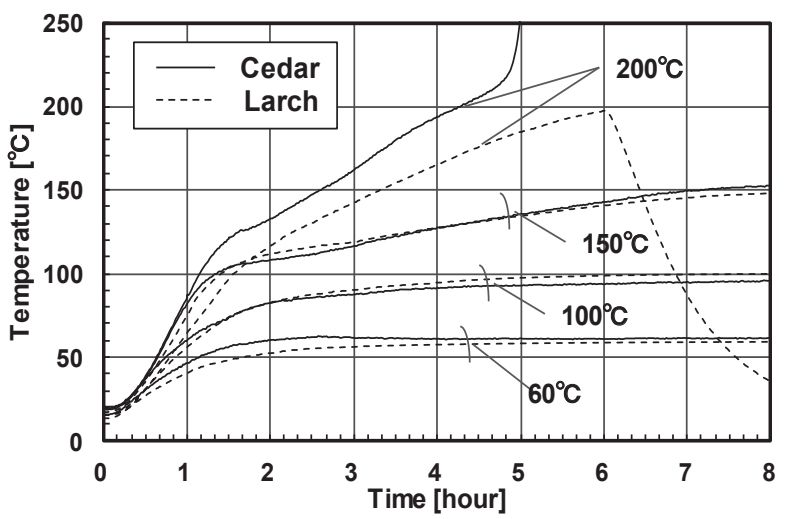

Fig. 6 Results of mean Temperature (Series I, 75×75mm)

圧縮強度を取得するまでに約 10 分の時間を要している。Fig.7 示すように自然放冷から 10 分後のスギの温度低下は, $60^{\circ} \mathrm{C}$ 加熱で $10^{\circ} \mathrm{C}, 100^{\circ} \mathrm{C}$ で $14^{\circ} \mathrm{C}, 150^{\circ} \mathrm{C}$ で $24^{\circ} \mathrm{C}, 200^{\circ} \mathrm{C}$ で $34^{\circ} \mathrm{C}$ であった。し たがって, 本実験で圧縮強度と試験体温度の関係を示すには, やや 正確性に欠けるが, 後述する Fig.10の温度には, ヒーターから取 り出す際の時間における試験体内部の平均值（1)～(3)）を採用し た。

\section{4 重量減少率の結果}

Fig.8 の (a)〜 (c)に各シリーズの重量減少率を示す。シリーズ I の

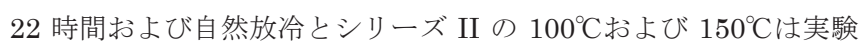
条件より 2 体行ったため, そのデータを示す。ここで述べる重量減 少率は, 加熱前の重量に対する加熱直後までの重量変化の割合であ る。重量減少率は, ヒーターの設定温度（以下, 加熱温度）が高い ほど，時間の経過に伴い増加した。Fig.8 の(a)に示す重量減少率の 傾き（以下, 重量減少速度）を見ると, 加熱温度 $150^{\circ} \mathrm{C} \cdot 200^{\circ} \mathrm{C}$ の場 合は加熱開始 1〜1.5 時間で比較的大きい。Fig.5の(a)より加熱開始 1.5 時間付近では, 内部温度が $100^{\circ} \mathrm{C}$ に至り温度勾配が緩やかにな る時間帯であり, 水分蒸発が多かったことが推測される。一方, 加 熱温度が $100^{\circ} \mathrm{C}$ 以下の場合は, 時間に概ね比例して重量が減少した。 Fig.8の(a)と(b)を比較すると, カラマツに対してスギの重量減少速 度は 3 時間まではやや大きい傾向にあるが, その後は大差がなくな った。断面が大きなシリーズ II の結果は, シリーズ I に比べて重量 減少速度は小さくなるが，1 日以上経過した後の重量減少率は同程 度であった。

\section{3. 高温加熱直後の圧縮実験結果}

\section{1 圧縮強度}

Fig.9 の (a)〜 (c)に圧縮強度と加熱時間の関係を, Fig.10の(a)〜 (c)に圧縮強度残存率と内部温度の関係をそれぞれ示す。0 分時にプ ロットした常温実験の結果より, 圧縮強度のばらつきが分かる。同 じ素材を用いた引張強度 9)および曲げ強度 10)の結果に比べて圧縮強 度のばらつきは小さく, 各条件 1 体の結果でも, 圧縮強度が加熱 時間により変化する傾向が分かる。Fig.9 の(a)に示すスギの結果よ り, 常温時圧縮強度の平均值 $34.0 \mathrm{~N} / \mathrm{mm}^{2}$ に対して加熱開始から 1 時間までの間に強度が大きく低下し, 圧縮強度が最小となる時間帯 は 1 2 時間であった。加熱温度が高いほど強度低下の速度が大き い傾向にあった。 $200^{\circ} \mathrm{C}$ の結果を除き，加熱開始 1 時間から 3 時間 の間で, 強度が小さいまま停滞する傾向にあり, 3 時間以降から強

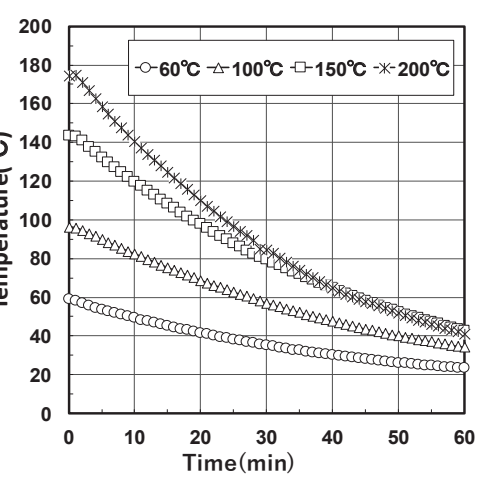

(a) Cedar

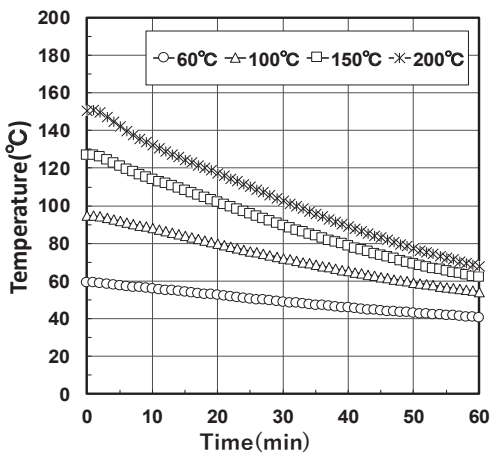

(b) Larch
Fig.7 Results of Additional heating test $(75 \times 75 \mathrm{~mm})$

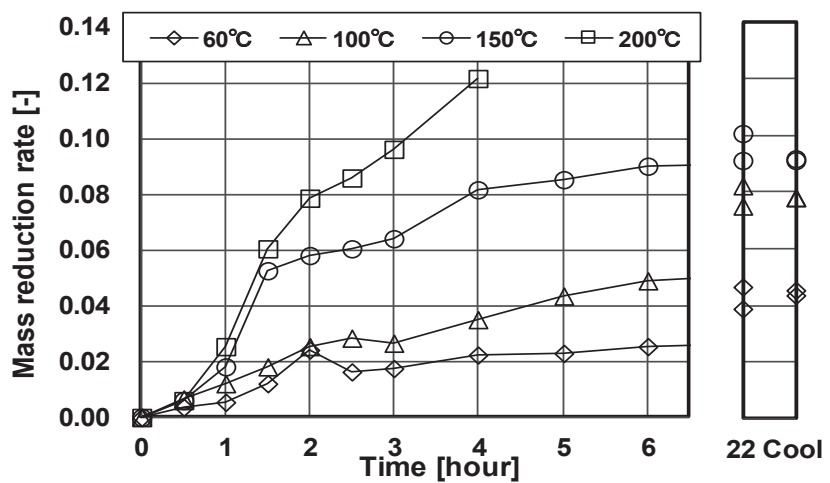

(a) Series I (Cedar, $75 \times 75 \mathrm{~mm}$ )

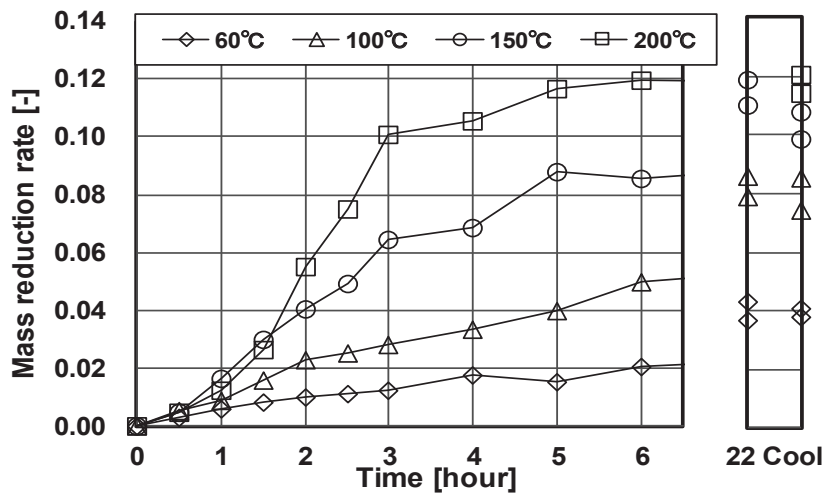

(b) Series I (Larch, $75 \times 75 \mathrm{~mm}$ )

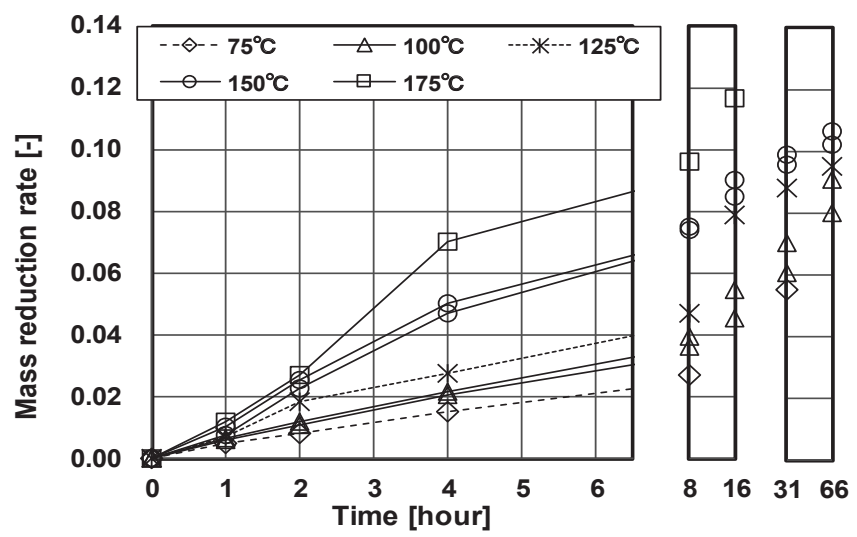

(c) Series II (Larch, 105×105mm)

Fig. 8 Mass reduction rate 


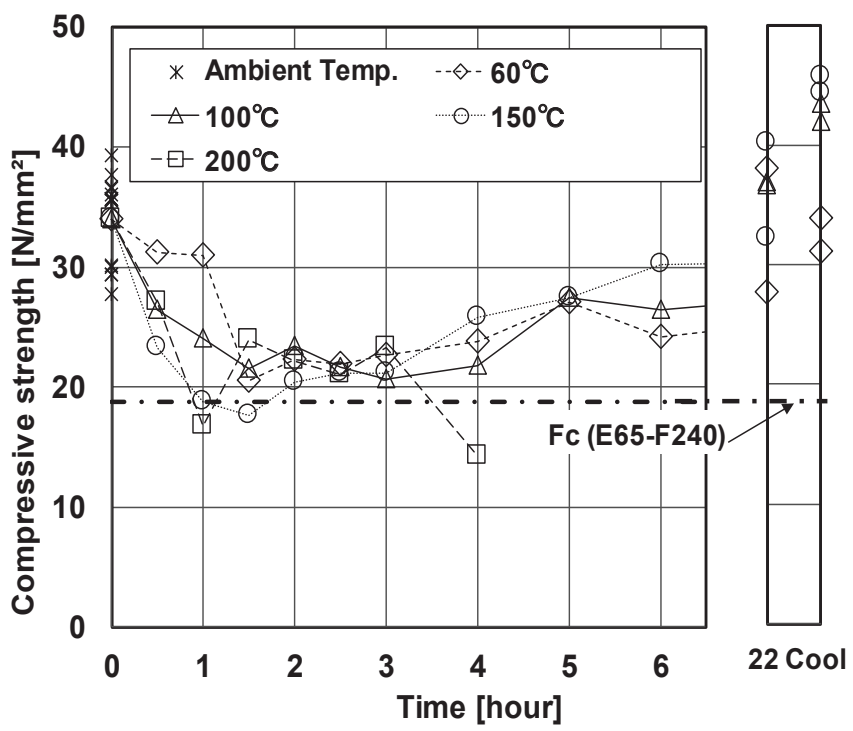

(a) Cedar (Series I, 75x75mm)

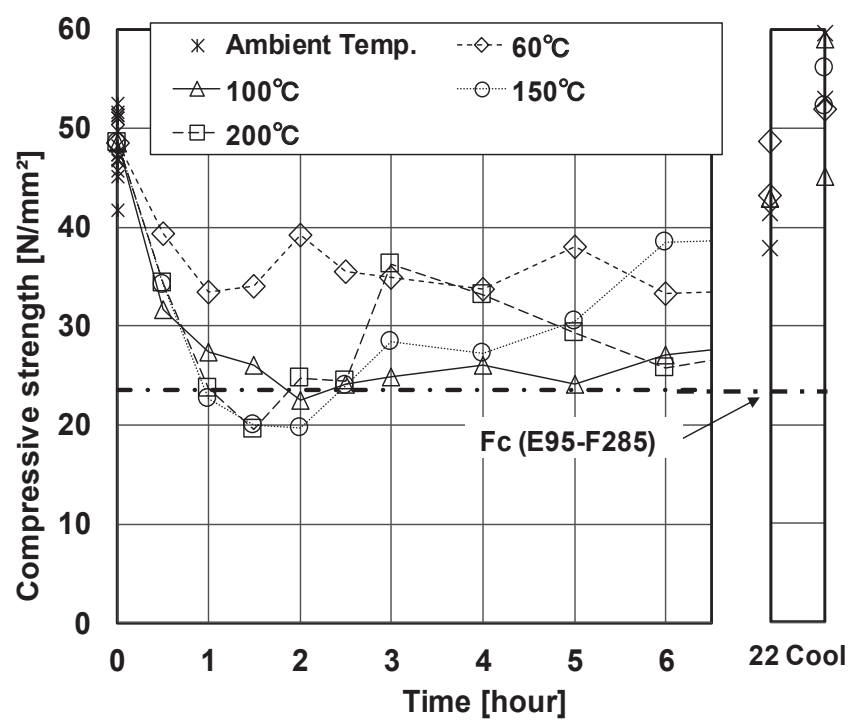

(b) Larch (Series I, 75x75mm)

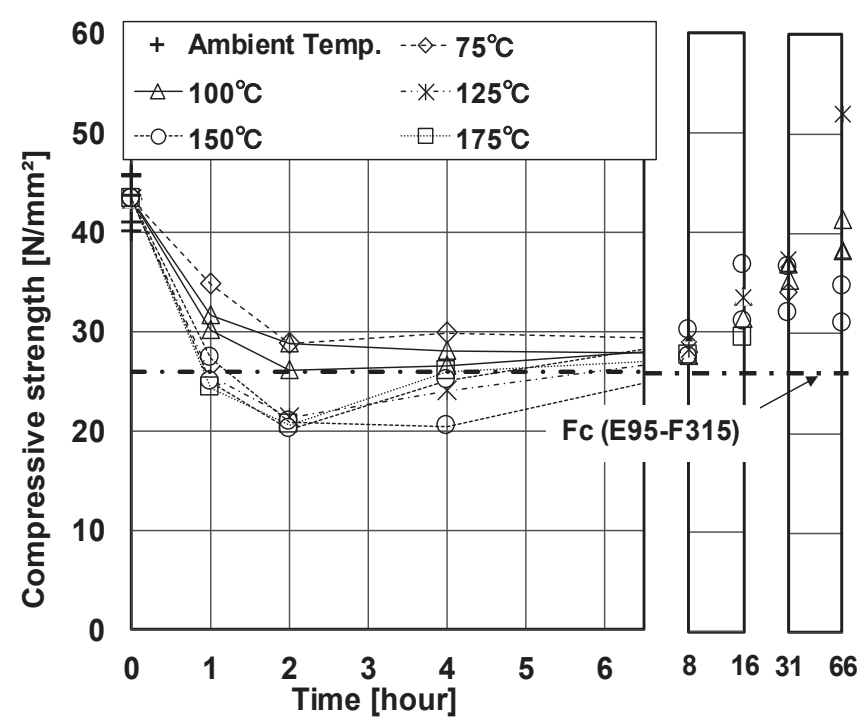

(c) Larch (Series II, 105×105mm)

Fig.9 Compressive strength

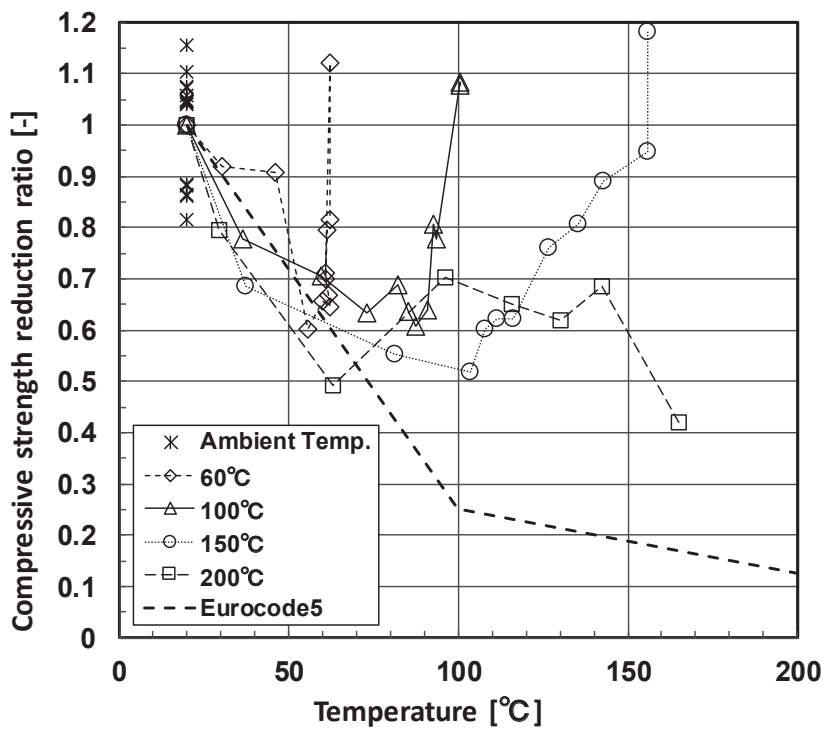

(a) Series I (Cedar)

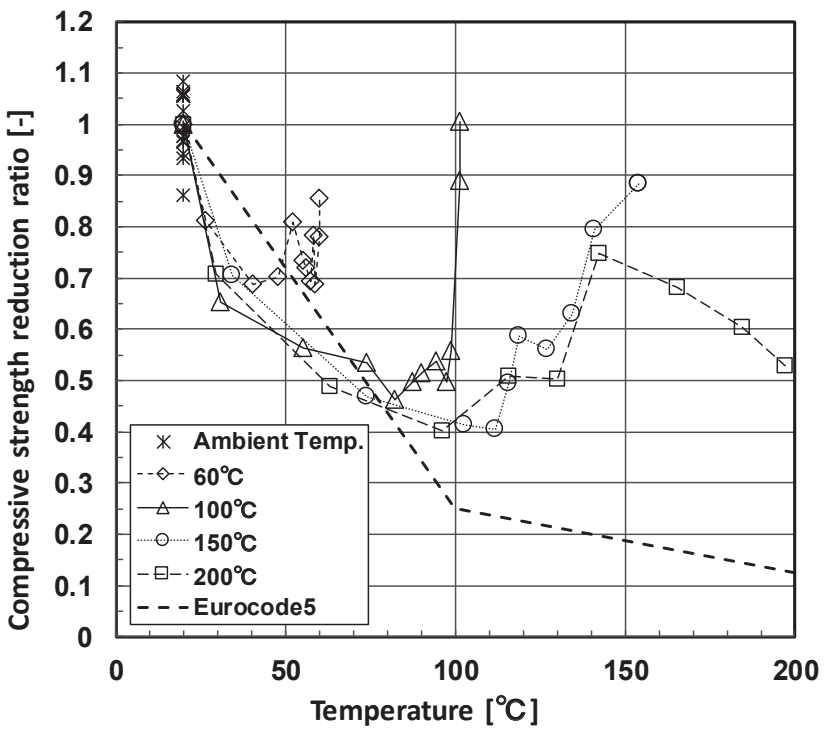

(b) Series I (Larch)

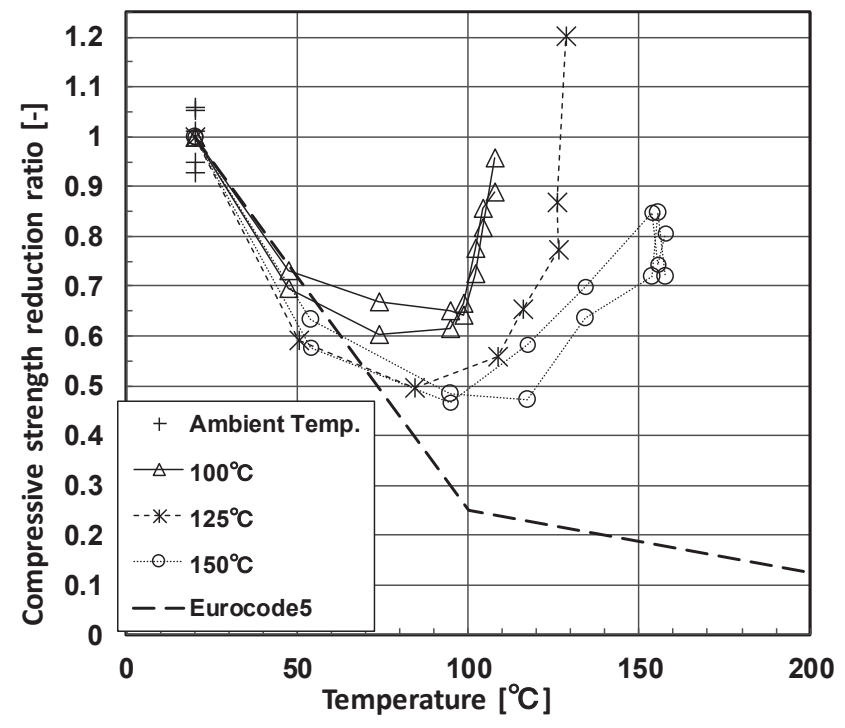

(c) Series II (Larch)

Fig.10 Compressive strength reduction ratio 
度の回復傾向が見られ，22 時間後の高温強度と加熱泠却後強度は 元の強度にまで回復した。Fig.9 の(b)に示す同シリーズのカラマツ でも，スギの結果と同様な傾向を示し，加熱開始 1 2 時間で圧縮 強度が最小となり, その後に強度の停滞が見られ, $150^{\circ} \mathrm{C}$ と $200^{\circ} \mathrm{C}$ は先行して強度が回復する傾向にあった。Fig.8の(a)と(b)に示す ように，スギの $200^{\circ} \mathrm{C}$ 結果を除いた $60^{\circ} \mathrm{C} \sim 200^{\circ} \mathrm{C}$ 加熱では， 3 時間以降でその前よりも重量減少の速度が小さくなっており, 水分 の蒸発が緩慢になっていたと考えられる。また, Fig.5 の(a)と(b) に示すように, 時間の経過に伴い断面内部の温度差が小さくなって おり, 水分の移動も緩慢になっていたと考える。以上から, 水分の 変化が小さくなるにつれて, 強度が回復したと考える。Fig.9の(c) に示す断面寸法が大きい場合は, 強度低下の速度がやや小さく, 加 熱開始から 2 時間後まで強度が低下し続け, その後はシリーズ I と 同様，停滞・回復の傾向にあった。全ての結果で加熱開始から 1 時間までの間に圧縮強度が大きく低下することに着目すると, その 時間帯は内部温度の上昇速度が大きいが未だ $100^{\circ} \mathrm{C} に は$ 到達してい ないこと (Fig.5 と Fig.6 を参照), 重量の変化はそれほど大きくな いこと（Fig.8 を参照）が分かる。したがって，この時間帯におけ る圧縮強度低下の要因は, 蒸気による熱軟化および水分移動による 含水率の変化などが考えられる ${ }^{12)}$ 。既往の高温曲げヤング係数の 結果に対して温度と含水率のそれぞれの影響度合いを考察した報告 13)では， $100^{\circ} \mathrm{C}$ 未満では含水率の影響が支配的であることが示唆さ れている。本実験では, 加熱開始から 1 時間までの重量減少がそ れほど大きくないため, 水分の移動が圧縮強度の低下に影響し, そ の後加熱時間が長くなるにつれてその水分移動が緩やかになり, 強 度の回復があったと考える。シリーズ I の加熱温度 $150^{\circ} \mathrm{C}$ と $200^{\circ} \mathrm{C}$ の 1 2 時間での結果に着目すると, Fig. 8 の(a)と (b)に示すように 重量減少速度は大きいが, その時間帯における強度低下は比較的小 さく, 圧縮強度が小さいまま保たれた。したがって $100^{\circ} \mathrm{C}$ 付近で水 分が蒸発している状況下では, 圧縮強度が更に大きく低下寸ること はなく, 低い強度を維持（停滞）したままであった。火災加熱を受 ける木質部材の非炭化領域の強度を設定する上では, 本実験では重 量減少速度（1時間当たりの傾き）が最も大きくなる, 加熱開始か ら 2 時間位までの挙動に着目すべきと考える。加熱時間が 2 時間 を超えると, Fig.8 に示すように重量減少速度が徐々に緩やかにな り, Fig.9 に示すように含水率の低下に伴う強度回復が始まった。

Fig.9 には実験結果に加えて, 圧縮に関する構造設計用の基準材 料強度 14）（以下, 基準圧縮強度と称す）を示している。この基準圧 縮強度に対して, 常温時の圧縮強度は 1.7〜2.1倍の值を示したが, 加熱開始から 1 時間後に下回るものがあった。一方, 要求耐火時間 に応じて燃えしろの深さを減じた断面で構造計算する燃えしろ設計 では非炭化領域の強度に基準材料強度の $2 / 3$ 倍の短期許容応力度を 用いるが 14), 本実験では短期許容応力度を下回るものはなかった。

Fig.10の(a)〜(c)に圧縮強度と温度の関係を示す。Fig.10の(a) と (b)の温度は Fig.1 に示す 3 点の内部温度の平均値（Fig.6 の温度と 同值) であり, Fig.10の(c)の温度は Fig.2 に示寸 3 点(1)〜(3)の内 部温度の平均值である。縦軸の圧縮強度残存率は, 常温実験による 圧縮強度の平均值に対する高温圧縮強度の割合である。図中には Eurocode 5 に示される針葉樹(softwood)の強度残存率も示す。 Eurocode 5 の圧縮強度残存率は, $100^{\circ} \mathrm{C}$ のきに 0.25 である。
Fig.10(a)〜 (c)の横軸に内部温度の平均值を採用したためか, $70^{\circ} \mathrm{C} 以$ 下では Eurocode5 の残存率を下回る結果もあったが, $100^{\circ} \mathrm{C}$ までの 実験結果と Eurocode5 の強度残存率は概㸚対応した。本実験では, Fig.10の(a)〜 (c)に示すように, 内部温度が $60 \sim 70^{\circ} \mathrm{C}$ に至るまでに 圧縮強度は大きく低下し, その後 $100^{\circ} \mathrm{C}$ 近くまでは強度が緩やかに 低下した。ただし, 内部温度が加熱温度に近づくにつれて, 重量減 少速度が緩やかになるため, 強度が回復した。常温〜 $70^{\circ} \mathrm{C}$ 位までは, 加熱温度が高いほど同温度での圧縮強度が小さくなる傾向が見られ た。スギとカラマツの圧縮挙動に大きな違いはなかった。Eurocode5 の圧縮強度残存率の検討を行った Konig らは, 乾燥による強度回復 挙動を認識した上で, $100^{\circ} \mathrm{C} \sim 300^{\circ} \mathrm{C}$ 領域が $100^{\circ} \mathrm{C}$ 以下の領域に比 べてかなり小さいことを踏まえ, 数值解析に用いる $100^{\circ} \mathrm{C} \sim 300^{\circ} \mathrm{C}$ の強度を大まかに設定したと述べている 6 。

以上に示した通り, 一定温度下に近い状態で実施する荷重漸増実 験では，圧縮強度は加熱時間に大きく依存する傾向があった。加熱 温度によって, 重量減少速度の早さにも違いが生じ, 木材内部の水 分移動と含水率の変化に大きな影響を与えたと考えられる。したが って, 木材の高温時強度を検討するためには, 載荷加熱実験のよう な一定荷重下での温度漸増実験をも実施することが望ましいと考え る。

\section{2 圧縮弾性係数}

Fig.11の(a)と(b)にシリーズ I の実験による圧縮弾性係数（以下, 弾性係数) と加熱時間の関係を示す。弾性係数は, Fig.4 に示す測定 区間 $150 \mathrm{~mm}$ における荷重一変位関係に基づき, 比例上限荷重を最 大荷重の $2 / 3$, 下限荷重を最大荷重の $1 / 15$ として, その間の勾配を 用いて計算した。変位の值は左右で計測した変位の平均值とした。 試験体によっては変形が片側に集中し左右の変位が異なるものもあ ったが，すべて同様に計算した。常温時の弾性係数は, 常温実験 15 体の結果のうち, 最大值と最小值を除いた 13 体の結果の平均值と した。常温時の弾性係数は, スギが $6.9 \mathrm{kN} / \mathrm{mm}^{2}$, カラマツが 12.6 $\mathrm{kN} / \mathrm{mm}^{2}$ であり, 基準弾性係数に対してそれぞれ 1.1 倍と 1.3 倍で あった。Fig.11の(a)と(b)に示す弾性係数と加熱時間の関係より, 高 温時における弾性係数にはばらつきが見られるが, 加熱によって弾 性係数が低下寸る現象は確認された。スギ・カラマツともに, 加熱 開始から 2 時間位までの間に弾性係数は低下し, 概ね $1 \sim 2$ 時間の 間で最小となり，常温時の弾性係数の約 0.5 倍まで低下したものも あった。一方, 常温時に対する高温時の弾性係数の低下は圧縮強度 の場合ほどは大きくなかった。Fig10(a)に示すスギの $200^{\circ} \mathrm{C}$ の結果 を除き, 加熱温度が高い場合ほど, 弾性係数がより低下する傾向に あった。また加熱 3 時間後位から弾性係数が徐々に増加することも 確認された。これらの挙動は圧縮強度の結果に対応しており, 弾性 係数が低下寸る挙動においても, 圧縮強度の場合と同様に水分の影 響を受けたと考えられる。

Fig.12の (a) と (b)に弾性係数と温度の関係を示す。図中横軸の温 度は前述した Fig.10 のものと同じである。縦軸の弾性係数残存率 は, 常温実験より得た弾性係数に対する高温時の弾性係数の割合で ある。Fig.12の(a)と(b)に示すように, ばらつきはあるものの全体的 に内部温度が $100^{\circ} \mathrm{C}$ 付近で最低值となり, $100^{\circ} \mathrm{C}$ 以降では水分の重 量減少が落ち着き, 弾性係数が回復する傾向も見られた。図中に Eurocode 5 に示される針葉樹の弾性係数残存率も示しているが，本 


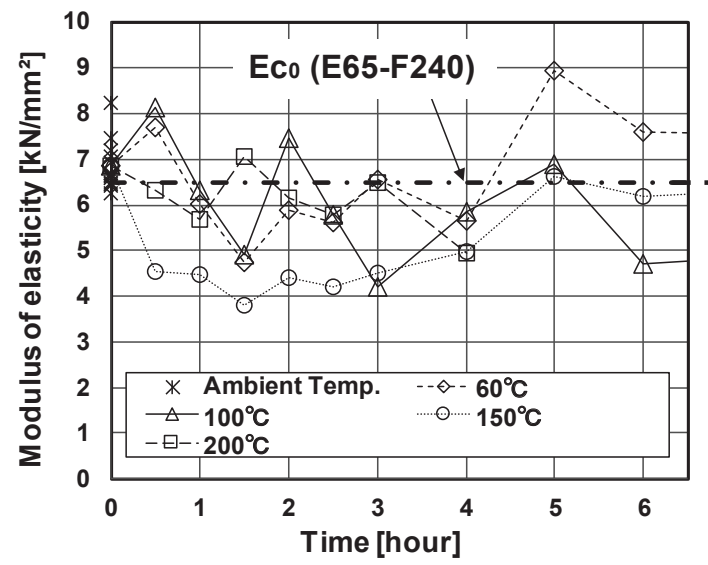

(a) Cedar

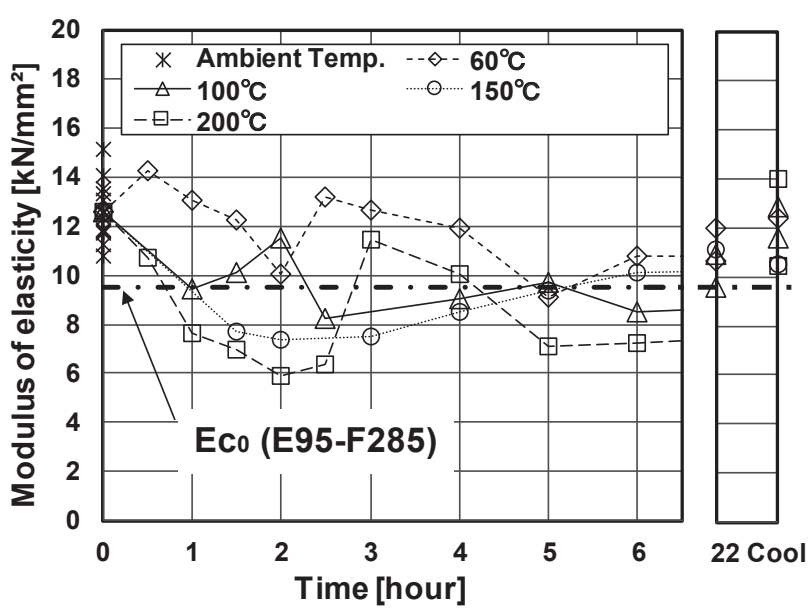

(b) Larch

Fig.11 Modulus of elasticity

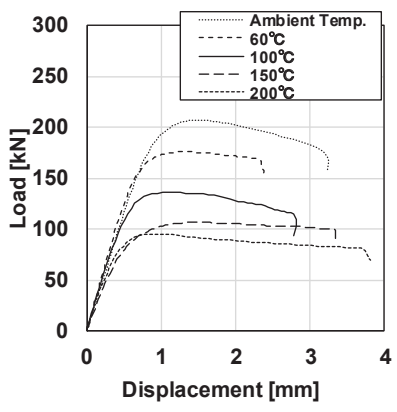

(a) Cedar, $1 \mathrm{~h}$

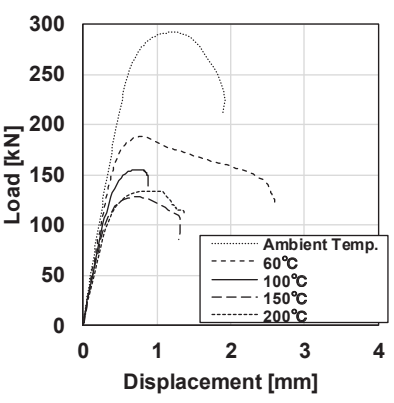

(e) Larch, $1 \mathrm{~h}$

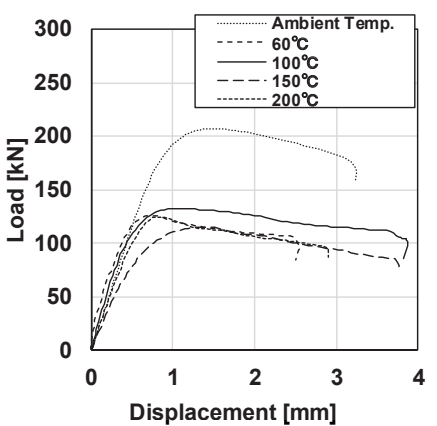

(b) Cedar, $2 \mathrm{~h}$

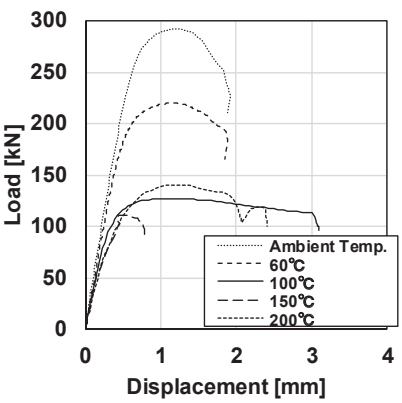

(f) Larch, $2 \mathrm{~h}$

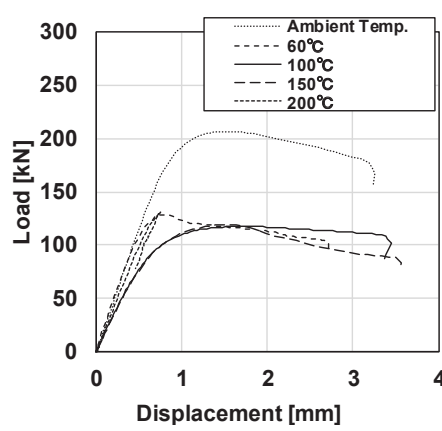

(c) Cedar, $3 \mathrm{~h}$

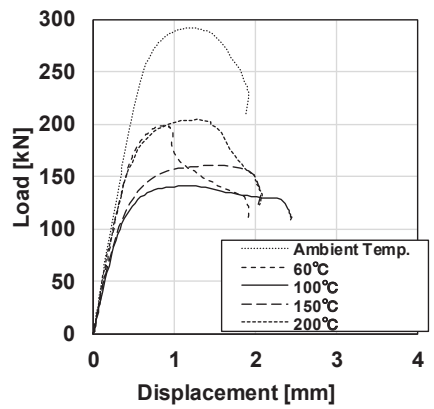

(g) Larch, 3h

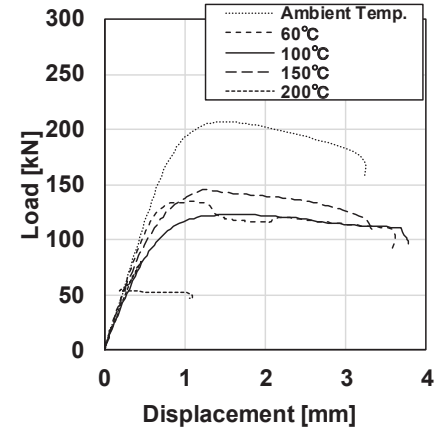

(d) Cedar, $4 \mathrm{~h}$

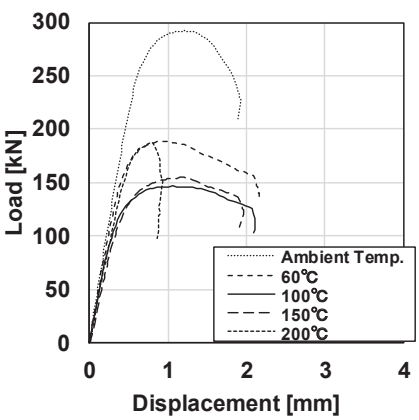

(h) Larch, 4h

Fig.13 Load-Displacement relationship (Series I ) 


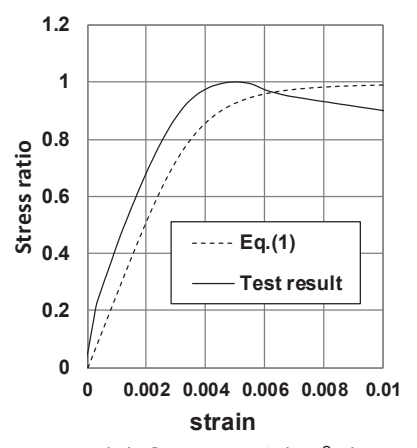

(a) Cedar $\cdot 2 \mathrm{~h}\left(60^{\circ} \mathrm{C}\right)$

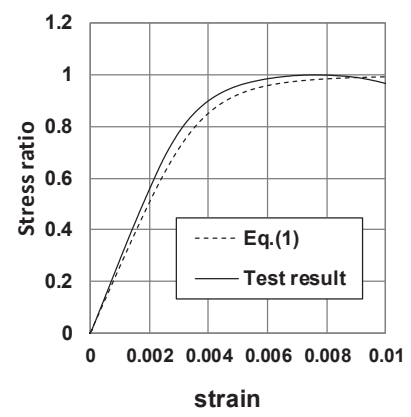

(e) Larch $\cdot 2 \mathrm{~h}\left(60^{\circ} \mathrm{C}\right)$

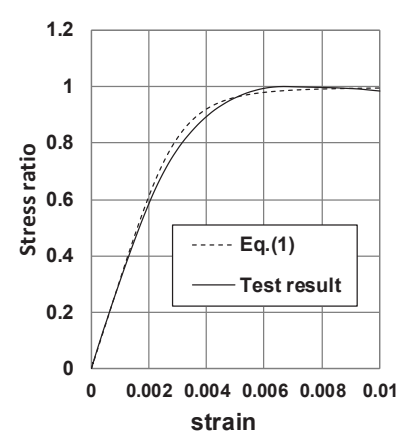

(b) Cedar $\cdot 2 \mathrm{~h}\left(100^{\circ} \mathrm{C}\right)$

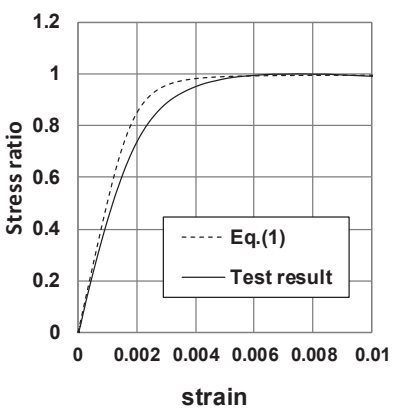

(f) $\operatorname{Larch} \cdot 2 \mathrm{~h}\left(100^{\circ} \mathrm{C}\right)$

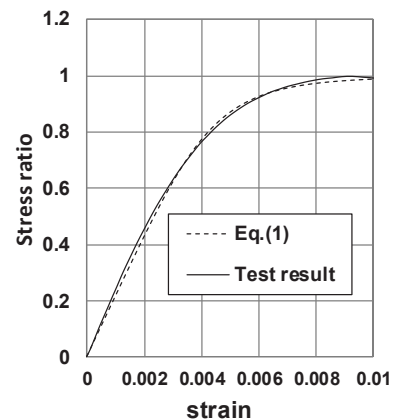

(c) Cedar $\cdot 2 \mathrm{~h}\left(150^{\circ} \mathrm{C}\right)$

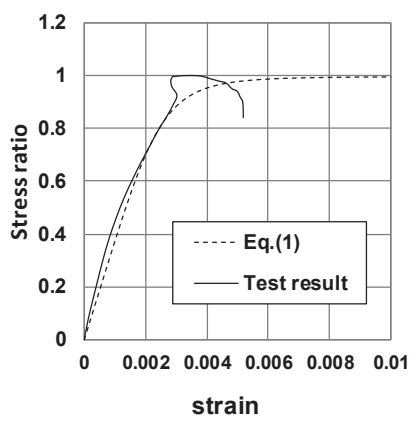

(g) Larch $\cdot 2 \mathrm{~h}\left(150^{\circ} \mathrm{C}\right)$

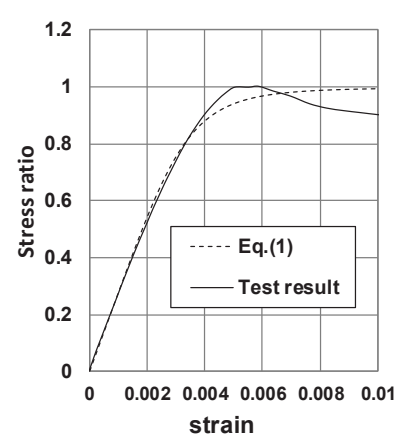

(d) Cedar $\cdot 2 \mathrm{~h}\left(200^{\circ} \mathrm{C}\right)$

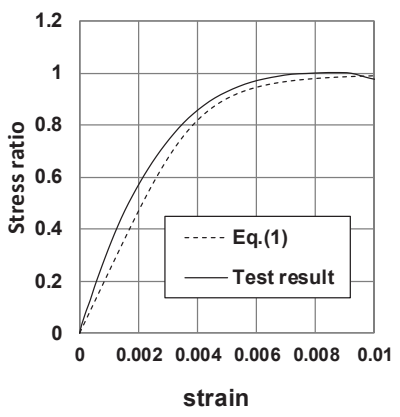

(h) Larch $\cdot 2 \mathrm{~h}\left(200^{\circ} \mathrm{C}\right)$

Fig.14 Stress-strain curve

実験より得た下限值は $100^{\circ} \mathrm{C}$ までの Eurocode 5 の低下勾配と概ね対 応した。

\section{3 荷重-変位関係}

スギの荷重一変位関係を Fig.13 の (a) (d), カラマツの荷重一変 位関係を Fig.13 の(e)〜 (h)に示す。比較のために, 各図とも常温実 験による荷重-変位関係の一例も示している。Fig.13 の(a)に示すス ギ・加熱時間 1 時間の結果を見ると, 加熱温度が高い（内部温度上 昇速度が大きい) ほど最大荷重と剛性の低下が見られた。Fig.13の (e)に示すカラマツ・加熱時間 1 時間の結果でも同様な傾向が見られ, 加熱初期の剛性と耐力は加熱温度の影響を受けることが確認された。 一方, 加熱時間 2 4 時間の結果を見ると, 加熱温度が高い場合に 剛性と耐力の大きくなるものがあり, 乾燥に伴う強度と弾性係数の 回復も見られた。Fig.13の(d)に示すスギ・加熱時間 4 時間の結果を 見ると, 加熱温度 $200^{\circ} \mathrm{C}$ における最大荷重が大きく低下したことが 分かる。

それぞれの荷重一変位関係を比較すると, 最大荷重に至るまでの 曲線の形に大きな差がないことが分かる。このことから，試験体の 温度 (加熱時間, 加熱温度) および樹種によらず，1 つの式で使用 木材の応力ーひずみ曲線を数式化することを試みた。具体的には, 次に示す Richard ${ }^{15)}$ の式(1)と式(2)を用いて数式化した。

$$
\begin{gathered}
\sigma=\frac{\left(E-E_{p}\right)}{\left\{1+\left|\frac{\varepsilon}{\varepsilon_{1}}\right|^{n}\right\}^{\frac{1}{n}}} \cdot \varepsilon \\
\varepsilon_{1}=\frac{\sigma_{c}-0.01 E_{p}}{E-E_{p}}
\end{gathered}
$$

ここで, $\sigma:$ 応力 $\left[\mathrm{N} / \mathrm{mm}^{2}\right], \varepsilon:$ ひずみ

$E:$ 弾性係数 $\left[\mathrm{N} / \mathrm{mm}^{2}\right], E_{p}$ : 硬化係数 $\left(E_{p}=\mathrm{E} / 1000\right)$

$\varepsilon_{1}$ : 漸近線の交点におけるひずみ, $\sigma_{c}$ : 圧縮強度 $\left[\mathrm{N} / \mathrm{mm}^{2}\right]$ $n$ : 応力-ひずみ曲線のとがり具合を表す係数 $(n=4.0)$

ここでは，上式における $E_{p}, \varepsilon_{1}, n$ の設定值における妥当性を確 認するため, 圧縮強度と弾性係数の值は実験結果を代入する。

前述した通り, 火災加熱を受ける木質部材の非炭化領域の高温力 学特性を設定する際は，水分の影響を受けてその剛性と耐力が最も 低下寸る時間を捉えるため, 本実験結果としては加熱開始から 2 時 間位までの挙動に着目した。そこで加熱 2 時間後の応力ーひずみ関 係の実験值と式(1)による值（以下, 計算値）を比較する。スギの結 果を Fig.14 の(a)〜(d), カラマツの結果を Fig.14 の(e)〜(h)に加熱 温度毎に示す。縦軸の応力比は, 当該実験で得た圧縮強度に対する 応力の比である。横軸のひずみは, 変位測定区間 $150 \mathrm{~mm}$ における 相対変位の結果による平均ひずみである。Fig.14の(a)では実験值の 初期剛性が大きな值を示した影響で計算值との差が見られ，また Fig.14の(g)ではひずみが 0.003 位のときに実験計測の不具合があ り計算值と乘離した。一方, その他の大半の結果では, 式(1)による 計算值が実験值と概初対応した。図中で比較する範囲をひずみ 0.01 までとした理由は，部材の耐火試験で ISO834 ${ }^{16)}$ に規定される限界 変形時の平均縁ひずみが 0.01 であり, 既往の木質構造の柱や梁の載 荷加熱実験結果 1), 2)ではその半分位の変形で破壊に至ることが多か ったからである。したがってひずみが 0.01 位までの応力ーひずみ曲 線を適切に与えることができれば，細長比が比較的小さな柱の座屈 荷重を接線係数理論にて計算可能となる ${ }^{2)}$ 。その際は, 式(1)中で $n$ の值が重要となるが, 本実験結果から $n=4$ と定めた。 


\section{4 破壊性状}

圧縮強度を取得した後に破壊させた試験体の様子を示す例として, 加熱温度 $150^{\circ} \mathrm{C}$ の例を Fig.15 の(a) と(b)に示す。スギ・カラマツと もに, 加熱時間 2.5 時間の例では, 幅方向の亀裂が局所的に生じて, やや斜めにずれながら圧壊した。その他の大多数の試験体の破壊性 状も同様であった。このタイプの破壊性状を示した試験体では, 最 大荷重以降，ひび割れが桩大しながら緩やかに荷重が低下した。一 方, 加熱時間 22 時間の例では, 材軸方向（繊維方向）全体に亀裂が 生じて, 縦に割れながら脆性的に破壊するものが多かった。節を通 る亀裂も見られ，節が起点となったような例もあったが，一辺が $75 \mathrm{~mm}$ 以上の本試験体では, 圧縮挙動に与える節の影響は比較的小 さかったと考える。今回の試験体の節は、生節と死節（抜け節）が あり、その節の補修は行っていない。

\section{4. まとめ}

スギとカラマツによる構造用集成材を対象として, 加熱温度と加 熱時間を実験条件とした圧縮実験を実施し, 高温時の圧縮挙動に及 ぼす水分の影響について検討した。以下にその結果をまとめる。

1）圧縮強度は, 加熱開始から 1 時間までの間に大きく低下し，1〜 2 時間の間で最小となった。その後は強度が停滞し, 4 時間以降 は乾燥に伴って強度が回復し, 22 時間後・冷却後は元の強度に まで回復した。

2）加熱開始から 1 時間までの間に圧縮強度が大きく低下した要因 は, 蒸気による熱軟化および水分移動による含水率の変化が大 きく影響していることが推察された。また, 内部温度が $100^{\circ} \mathrm{C}$ 程度に達し, 重量変化が最も大きかった $1 \sim 2$ 時間の間では, 圧 縮強度が低下したまま停滞している状態であった。

3）試験体の断面平均温度が常温〜 $70^{\circ} \mathrm{C}$ に至るまでの間に圧縮強度 が大きく低下することを示し，常温強度に対する強度残存率は， Eurocode5 で示される $100^{\circ} \mathrm{C}$ までの強度残存率に近い值を示し た。

4）高温時における圧縮弾性係数の低下は, 圧縮強度の結果と概补 同様であったが，常温値に対する残存率は圧縮強度より大きか った。また，圧縮強度の場合と同様に水分の影響が見られた。

5）弾性係数残存率は, ばらつきは多いものの, 内部温度が $100^{\circ} \mathrm{C}$ 付近で最低值となり, 実験結果の下限值は Eurocode 5 の低下勾 配と近い值を示した。

6）荷重一変位関係より，加熱開始 1 時間での剛性・耐力は加熱温 度が高い（内部温度上昇速度が大きい）ほど小さくなる傾向が 確認された。

7）圧縮域に関するひずみ $1 \%$ までの応力ーひずみ曲線を, Richard 式によって近似できることを示した。

8）加熱時間 2.5 時間位までの場合は, 最大荷重以降, ひび割れが 大きくなりながら緩やかに荷重が低下し, 脆性的な破壊性状を 示すものが少なかった。

引き続き実験データの蓄積を行い，木材のばらつきによる検討を 行うことが今後の課題である。また, 今後は載荷加熱実験のような 一定荷重下での温度漸増実験をも実施し, 高温時の強度を検討する 必要もあると考える。

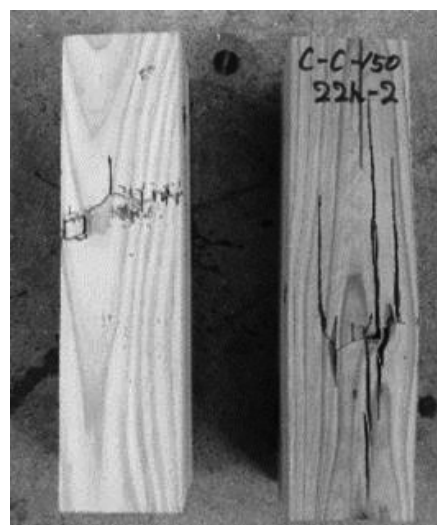

(a) Cedar, left: $2.5 \mathrm{~h}$, right: $22 \mathrm{~h}$

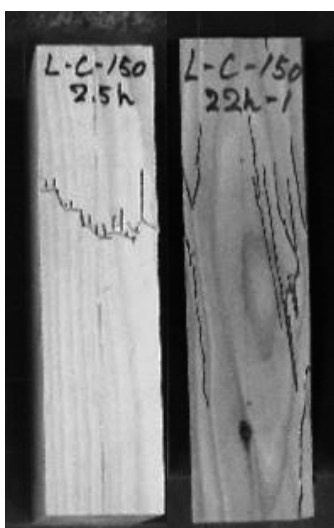

(b) Larch, left: $2.5 \mathrm{~h}$, right: $22 \mathrm{~h}$
Fig. 15 Examples of failure of the specimens (Series I, $150^{\circ} \mathrm{C}$ )

\section{謝辞}

本報に示すシリーズ I の実験は，国土交通省平成 28 年度住宅・ 建築物技術高度化事業の助成を受け，大成建設・日本集成材工業協 同組合・日建設計との共同研究の一部として実施された。シリーズ II の実験は, ベターリビング・齋藤木材工業との共同研究の一部 として実施された。また千葉大学工学部建築学科の火災工学研究室 のメンバーの協力の下で実験は実施された。関係各位に謝意を表 す。

\section{参考文献}

1) H. Kinjo, S. Yusa, T. Horio, T. Hirashima, T. Matsumoto, K. Saito, Behaviours of Larch Glued Laminated Timber Beams Exposed to Standard Fire Heating During the Cooling Phase -Study on fire performance of structural glued laminated timber beams Part 1-, Journal of Structural and Construction Engineering (Transactions of AIJ), Vol. 80, No. 711, pp.831-840, 2015.5 (in Japanese)

金城仁，遊佐秀逸，堀尾岳成，平島岳夫，松本匠，齋藤潔 : 標準火災加熱を受 けたカラマツ集成材梁の放冷過程における挙動, 構造用集成材梁の耐火性に関 する研究 その 1 , 日本建築学会構造系論文集 第 80 巻 第 711 号, 831-840, 2015. 5

2) T. Igarashi, S. Ishii, H. Yamashita, S. Baba, T. Someya, T. Hirashima, Buckling Strength and Failure time of Japanese Cedar and Larch Glued Laminated Timber Columns Exposed to Fire, Journal of Structural and Construction Engineering (Transactions of AIJ), Vol. 85, No. 770, pp.639-649, 2020.4 (in Japanese).

五十嵐 樹, 石井 俊吾, 山下 平祐, 馬場 重彰, 染谷 朝幸, 平島 岳夫:火災 加熱を受けるスギ・カラマツ構造用集成材柱の座屈耐力および破壊時間, 日本建築学会構造系論文集 第 85 巻 第 770 号, pp.639-649, 2020.4

3) C. C. Gerhards, Effect of Moisture Content and Temperature of the Mechanical Properties of Wood: An Analysis of Immediate Effects, Wood and Fiber, 14 (1), pp. 4-36, 1982

4) Eurocode5: Design of timber structures - Part 1-2: General - Structural fire design, 2004

5) J. Konig, Structural Fire Design According to Eurocode 5 -Design Rules and Their Background, Fire and Materials, 29, pp.147-163, 2005

6) J. Konig, L. Walleij, Timber Frame Assemblies Exposed to Standard and Parametric Fires -Part.2 A Design Model for Standard Fire Exposure, Rapport I 0001001, Swedish Institute for Wood Technology Research: Stockholm, 2000

7) T. Kaku, et al, Influence of Water Content on the Mechanical Properties of Wood Exposed to Fire - Young's Modulus and Bending Strength of Cryptomeria Japonica and Zelkova Serrate under Various water-containing States at Elevated Temperature -, Journal of Structural and Construction Engineering (Transactions of AIJ), Vol. 85, No. 769, pp. 451-453, 2020.3 (in Japanese) 加來千紘, 長谷見雄二, 上川大輔, 鈴木達朗, 安井昇, 腰原幹雄, 長尾博文: 含水率が火災加熱を受ける木材の力学的性能一及ぼす影響一多様な含水状 
態におけるスギ及びケヤキの高温時ヤング係数・曲げ強度の測定一, 日本 建築学会構造系論文集 第 85 巻 第 769 号,pp. 451-453, 2020.3

8) S. Watanabe, et al, Dependence of Mechanical Properties of Wood on Temperature, Moisture Content and Tree Species at Elevated Temperature - Measurement of Young's Modulus and Bending Strength on Major Structural Tree Species and Examination of the Predictability of the Mechanical Properties at Elevated Temperatures Based on Basic Material Properties -, Journal of Structural and Construction Engineering (Transactions of AIJ), Vol. 84, No. 761, pp. 1011-1020, 2019.7 (in Japanese)

渡辺秀太, 鈴木達朗, 長谷見雄二, 加來千紘, 上川大輔, 安井昇, 宮本康 太 : 多様な樹種の木材の力学的性能に対する温度 - 含水率の影響の把握と 予測可能性, 構造用主要樹種に関するデータ構築と全乾密度に基づく予測 可能性の検討, 日本建築学会構造系論文集 第 84 巻 第 761 号, pp. 1011$1020,2019.7$

9) Y. Katakura, T. Matsumoto, T. Hirashima, H. Kinjo, K. Saito, Effect of Moisture Evaporation on Strength of Larch-glulam at High Temperature, Summaries of Technical Papers of Annual Meeting, Architectural Institute of Japan, Fire Safety, pp.131-134, 2015.7 (in Japanese)

片倉佑介, 松本匠, 平島岳夫, 金城仁, 齋藤 潔 : カラマツ集成材の高温時 強度に及ぼす水分蒸発の影響, 日本建築学会大会学術講演梗概集, 防火, pp.131-134, 2015.7

10) M. Ichikawa, S. Baba, T. Kataoka, T. Someya, T. Hirashima, Mechanical Properties of Cedar and Lurch of Structural Glued Laminated Timber at High Temperature, Summaries of Technical Papers of Annual Meeting, Architectural Institute of Japan, Fire Safety, pp.357-360, 2017.7 (in Japanese)

市川萌都，馬場重彰，片岡辰幸，染谷朝幸，平島岳夫 : 高温加熱を受ける スギ・カラマツ構造用集成材の力学的特性, 日本建築学会大会学術講演梗 概集，防火, pp.357-360, 2017.7

11) H. Ido, S. Miura, H. Nagao, H. Kato : Strength properties of kuri (Japanese chestnut, Castanea crenata) timber Bending strength, compressive strength parallel to the grain, tensile strength parallel to the grain, shear strength parallel to the grain, and compressive strength perpendicular to the grain, Bulletin of FFPRI, Vol.12, No.3, pp.143-152, 2013.9(in Japanese)

井道裕史，三浦祥子，長尾博文，加藤英雄：クリ製材品の強度性能-曲げ, 縦圧縮, 縦引張, せん断, めり込み-, 森林総合研究所研究報告, Vol.12, No.3, pp.143-152, 2013.9

12) A. H. Buchanan, Structural Design for Fire Safety, Chapter 10 Timber Structures, JOHN WILEY \& SONS, LTD, 2002

13) T. Suzuki, Y. Hasemi, D. Kamikawa, N. Yasui, C. Kaku, S. Watanabe, Development of an Equation Calculating Young's Modulus Remaining Ratio with Temperature and Moisture Content within Wooden Members Exposed to Fire Heating, Journal of Structural and Construction Engineering (Transactions of AIJ), Vol. 85, No. 770, pp. 651-661, 2020.4 (in Japanese)

鈴木達朗, 長谷見雄二, 上川大輔, 安井昇, 加來千紘, 渡辺秀太 : 火災加 熱される木質部材内部の温度・含水率によるヤング係数残存率計算式の導 出, 日本建築学会構造系論文集 第 85 巻 第 770 号, pp. 651-661, 2020.4

14) Architectural Institute of Japan: Standard for Structural Design of Timber Structures, 2006 (in Japanese) 日本建築学会 : 木質構造設計規準・同解説，2006

15) Richard, R.M, and Abbott. B. J.: Versatile elastic-plastic stress-strain formula, Journal of Engineering Mechanics, ASCE, Vol.10, No.4, pp.511-515, 1975

16) ISO 834-1: Fire-resistance tests - Elements of building construction - Part 1 : General requirements, 1999 


\title{
INFLUENCE OF MOISTURE ON COMPRESSIVE BEHAVIOR OF JAPANESE CEDAR AND LARCH STRUCTURAL GLULAM TIMBERS AT ELEVATED TEMPERATURE
}

\author{
Takayuki KIKUCHI ${ }^{* 1}$ and Takeo HIRASHIMA*2 \\ ${ }^{* 1}$ Grad. Student, Graduate school of Science and Engineering, Chiba Univ., M.Eng./ \\ Tech. Staff, Faculty of Engineering, Chiba Univ. \\ ${ }^{*}$ Prof., Graduate School of Engineering, Chiba Univ., Dr.Eng.
}

Regarding the load-bearing capacity of timber elements subjected to fire heating, knowledge of not only the charring behavior but also the mechanical properties at elevated temperature are required because the temperature of the noncharring area gradually increases during the cooling decay phases in fire. Therefore, in order to predict the fire resistance of timber elements, it is necessary to grasp the changes in strength and elastic modulus of the timber materials with temperature rise.

In this study, elevated temperature compression tests of structural glulam timbers made of Japanese cedar and larch were carried out for the purpose of understanding the influence of moisture in the timber on the compressive behavior at elevated temperature. The tests parameters were tree species, furnace temperature condition below $200{ }^{\circ} \mathrm{C}$, and heating time. Influences of moisture in the specimens on the compressive behavior were discussed from the test results on the relationships of heating time and weight changing. Another purpose was to obtain a numerical model of stressstrain curves at elevated temperature to analysis the fire resistance of timber elements.

Main findings of this study were summarized as follows:

(1) Compressive strength at elevated temperature decreased significantly from the start of heating to 1 hour, and became the minimum during 1 to 2 hours. After that, the strength recovered with drying, and finally, it returned to the strength at ambient temperature.

(2) The reason why the compressive strength decreased significantly from the start of heating up to 1 hour was that the steam softening and the change of water content due to migration of the moisture had a great influence ${ }^{12)}$.

(3) Compressive strength of both Japanese cedar and larch decreased significantly when the internal temperature of the timber increased from ambient temperature to $70^{\circ} \mathrm{C}$, and the lower values of the results up to around $100^{\circ} \mathrm{C}$ were close to the strength ratio of Eurocode5.

(4) The modulus of elasticity at elevated temperature decreased significantly from the start of heating to 1 hour, and became the minimum during 1 to 2 hours, similar to change of the compressive strength.

(5) Results of the load-displacement relationships indicated that the decrease of the rigidity and the maximum load in the initial stage of heating depended on the temperature rising rate.

(6) The stress-strain curve for compression within 1\% strain was approximated by Richard's equation. 